\title{
Decentralised development policy: A comparative study on local development interventions through municipalities in Sweden
}

European Urban and Regional Studies $1-15$ (C) The Author(s) 2021

\section{(c) (i)}

Article reuse guidelines: sagepub.com/journals-permissions DOI: 10.1 I 77//096977642। I 054773 journals.sagepub.com/home/eur @SAGE

\author{
Brita Hermelin (iD) and Kristina Trygg (D) \\ Linköping University, Sweden
}

\begin{abstract}
This article investigates how the international wave of decentralisation of development policy, promoted through ideals of place-based policy, becomes practice through development interventions made by municipalities in Sweden. Based on an extensive empirical study across Swedish municipalities, the article contributes with knowledge about how the decentralisation of development policies is formed through a combination of shared and relatively heterodox conditions for development interventions across the different categories of municipalities: cities, towns and rural settlements. The results describe the varying scope of local development interventions and how decentralisation involves differentiating the involvement of municipalities into vertical and horizontal relations within the planning sector. The article's findings about the variations in local development interventions across the different categories of municipalities contribute to the debate within geography on the varying capacities of different geographical formations to mobilise for bottom-up development, leading to the weaker regions remaining weak. The results of this article also illustrate the importance of reflecting upon how particular national planning systems shape the implications of the general international trend towards the decentralisation of local development policy.
\end{abstract}

\section{Keywords}

local development interventions, decentralisation, local development policy, municipalities, Sweden

\section{Introduction}

During the last few decades, there has been a growing debate about what is described as a general and continuing trend towards decentralising development policy (Pike et al., 2017; Rodriguez-Pose and Sandall, 2008). Local development policies have been established in advanced countries (O'Brien and Pike, 2019; Schneider and Cottineau, 2019; Vázquez-Barquero and Rodríguez-Cohard, 2016), for which local and regional planning bodies are important actors (Brenner, 1999; Rodríguez-Pose and Gill, 2004). This decentralisation of government is described as an effect of the global post-Keynesian wave of rescaling policy interventions (Brenner, 2003; Jonas and Moisio, 2018; McCann, 2017;

\footnotetext{
Corresponding author:

Brita Hermelin, Centre for Local Government Studies (CKS), Linköping University, Norrköping, CKS, 601 74, Sweden.

Email: brita.hermelin@liu.se
} 
Muringani et al., 2019; Roodbol-Mekkes and van den Brink, 2015; Tomaney, 2014), which shows "signs of new "regionalism" and "localism"” (Martin, 2001: 204).

Support for a 'decentralisation discourse' (Rodriguez-Pose and Sandall, 2008) and a placebased approach to growth strategies is interlinked and shared across powerful international bodies, including the European Union (EU) and the Organisation for Economic Co-operation and Development (Barca, 2009; OECD, 2011). Scholarly works within geography and regional studies have explored the conditions and values of the decentralisation of development interventions and how this integrates a place-based and bottom-up approach into development strategies (Bailey et al., 2018; Barca et al., 2012; Bowden and Liddle, 2018; Broadhurst, 2018; Morisson and Doussineau, 2019; Rodríguez-Pose, 2013). However, in important ways, this discourse about the need to work from the bottom up for development interventions has been introduced in a top-down manner. The increased expectations on local and regional political bodies to become involved in development policy interact with an increased adoption of this ideal and, thus, influence the motivations among sub-national actors to become engaged in development interventions. In this way, the trend towards decentralising development policy is augmented by the interplay between top-down and bottom-up processes. Decentralisation can be interpreted as a bottom-up discourse enabled by top-down actors in the way that it advocates 'a developmentalist approach aiming at maximizing the development potential of all regions' (Barca et al., 2012: 146), and that the values of economic development have become 'a central justification for the decentralisation of power' (Rodriguez-Pose and Sandall, 2008: 69).

Nevertheless, although a decentralised approach is promoted, the debate is also careful about how it envisions the challenges faced by local interventions seeking to solve regional problems (Barca et al., 2012; Parr, 2015). It is also important to understand that decentralisation may refer to many different aspects, among which delegation and devolution are distinct. Delegation refers to the transfer of policy responsibility, while central government remains accountable in important ways. In contrast, devolution refers to stronger autonomy for local bodies in the making of policy (Pike et al., 2016). Decentralisation may be administrative or political, formal or informal (Persson and Kitagawa, 2021), and it is important to consider the ways in which it also involves the decentralisation of the resources available to support planning bodies to act and make interventions. Overall, different facets of decentralisation are assumed to induce different formations of relations between planning levels.

The decentralisation of development interventions implies increased expectations being placed on local political bodies to develop strategic policies for growth and strategies for development interventions (Pike et al., 2017; Tomaney, 2014). There is proliferating research on local development strategies for different empirical contexts and for different target areas. Scholarly debate on variations in adopting policy ideals for specific places involves exploring place branding practices (Cleave and Arku, 2017), ideals of smart cities (Crivello, 2015; McCann and Ward, 2015; Viitanen and Kingston, 2014), creative city strategies (Oancă, 2015; Prince, 2012, 2014) and models for sustainable development (Temenos and McCann, 2012), to give just a few examples. In contrast to such single-case or comparative-case studies for particular target areas that are becoming so common within this research debate, this article endeavours to contribute with knowledge from an empirical study with an extensive research design that compares categories of municipalities within a shared national context, which is Sweden.

Against this background, the aim of this article is to investigate how the decentralisation of development policy is adopted through local planning and how this varies across different geographical environments. The empirical material for this investigation is derived from a questionnaire survey distributed to all Swedish municipalities. The categories of municipalities that were selected and compared in this article are cities, towns and two different types of rural settlements. The results of this study can be used to describe how increased expectations being placed on local political bodies to manage development interventions are adopted across different categories of municipalities and how the 
decentralisation involves varying formations of relations across planning levels. Finally, through reflecting on the planning structure for Sweden, which is the context for this empirical study, a discussion is developed about how the particularities of national planning systems impact upon what the decentralisation of development policy implies 'on the ground'.

The article proceeds in the second section with a literature background that develops the discussions introduced above about the decentralisation of development interventions and how the geographical scale of local environments conditions local development interventions. The third section describes the design of the empirical study. The fourth section presents the results, and the fifth section contains the concluding discussion.

\section{Literature background: decentralisation of development interventions}

For this article about the engagement of Swedish municipalities with development policy, the debate on the decentralisation of development policy for countries in the EU is of particular relevance (Rodríguez-Pose, 2013; Rodríguez-Pose and Gill, 2004; Swyngedouw, 2000). This involves debates on rescaling within a hierarchy of political scales and how various planning tasks migrate between levels of the planning system (Keating, 2021). There have been very few studies on how such rescaling takes place in the Nordic region, of which Sweden is representative, and it is envisioned that the strong welfare tradition of these countries will impact upon the specific ways in which rescaling is adopted (Pelkonen, 2016).

While this discussion on rescaling refers to political levels, that is, the national, regional and local levels, and the metaphor of a hierarchical ladder (Crawford, 2020), taking a relational approach to political scales (Gualini, 2006) means that the conception of scales needs to be 'defined by the political relations that constitute it, rather than existing as a pregiven arena' (MacKinnon, 2011: 30). This means conceiving of rescaling as involving a reorganisation of scalar relations for shared responsibilities (Brenner, 2003). Spatial scale should be understood as something that is produced historically (Swyngedouw, 2000: 70-71). It has been argued that 'the important aspect of place-based development is that scales are negotiated through the policy-making process rather than being predefined' (Puglalis and Gray, 2016: 195). The decentralisation of interventions for the development of regions and cities (Rodríguez-Pose, 2020) is also about 'outward' rescaling processes, which shape the horizontal relationships between 'geographically non-contiguous cities and regions' (Pelkonen, 2016: 160).

The openness and readiness of sub-national planning bodies to adopt policy models from outside vary, and this has an impact on how development interventions are made (Barca et al., 2012). This 'outside' may be represented by higher levels of policy and top-down policy programmes, such as the means by which EU programmes have extensive impacts on the formation of interventions at a local scale for countries in Europe. The various impacts of programmes for development interventions also depend on how local policy actors are integrated into information sharing and learning (Moodysson et al., 2017), which relates to the varying organisational capacities of municipalities of different sizes. Overall, this discussion highlights the importance of understanding the decentralisation of development policy through how it involves and is formed through interactions within and between political scales.

The decentralisation discourse is described as assuming values of identity, good governance and economic efficiency. The concept of good governance is associated with capabilities for "strengthening civil society," "building social capital," or "improving participation," all frequently associated with the decentralisation project' (Rodriguez-Pose and Sandall, 2008: 57). Planners and political scientists propose that local planning actors' operations in city-regions are structured in a more efficient and functional way than those of the nation-state ( $\mathrm{Li}$ and Jonas, 2019; Neuman and Hull, 2009). This also relates to the aims of achieving efficiency and competitiveness through strategies for endogenous development, continuous innovation and a growth perspective (Bachtler and Yuill, 2001). Locally grounded strategies for development are said to be 'more likely to be successful if they are 
"multidimensional", (Rodríguez-Pose and Wilkie, 2019: 24), involving relationships across sectors and the coordination of different social actors with different interests (Vázquez-Barquero and RodríguezCohard, 2016).

Nevertheless, although a place-based approach is often seen as an opportunity to achieve economic growth for different places and regions, critical challenges to the place-based approach to growth policy have been described (Barca et al., 2012). These include how the decentralisation of policy interventions for economic growth may involve the fragmentation of policies as they percolate through layers of local and regional governments (O'Brien and Pike, 2019; Schneider and Cottineau, 2019). Variations across local governments lead to different institutional capacities, such as "planning (and lobbying) capabilities' (Crescenzi and Giua, 2016: 2341), and capacities for absorbing funds (Farole et al., 2011; Montresor and Vittucci Marzetti, 2011; Morisson and Doussineau, 2019: 102; Oughton et al., 2002). It has been argued that the structures of regional differences are an inbuilt aspect of regional development policy that is embedded within a competitiveness-oriented ideal of development (Pelkonen, 2016). An empirical analysis of the effects of EU cohesion policy concludes that a bottom-up approach for regional development policy is not very effective in the most deprived areas (Crescenzi and Giua, 2016: 2341). Earlier research, sensitive to the fact that the local level refers to quite heterogeneous contexts, has illustrated capacity constraints for small municipalities (Hytönen and Ahlqvist, 2019) and particular conditions for development among second-tier (or second-rank) cities (Camagni and Capello, 2015). It has been found that regional policies often fail to deliver to rural settlements within disadvantaged areas (Huggins and Clifton, 2011; Kline and Moretti, 2014; Neumark, 2020). This motivates arguments that the decentralisation of development policy needs to make distinctions between local environments of different scale dimensions and development trajectories (Iammarino et al., 2019).

Reflections on these challenges consider the scale of sites and local planning bodies, that is, the municipalities, which in more concrete terms involve factors such as the size of the local population, employment, industry and the public sector. This also means understanding the divergence between political-administrative territories and functional regions for labour-market and economic activities, which are organised through relations and networks. These aspects of the varying sizes of municipalities, varying local structures for settlements and economic activities, and the different structures of functional regions have impacts on the local capacity to involve actors and harness resources across multiple scales and localities to stimulate local development (Farole et al., 2011). These aspects, with their impacts on the capacities of municipalities, are important backgrounds for how the local development interventions take form through relations across political scales and places. Overall, this approach to the different conditions of municipalities is helpful in revealing how the local level within a planning system, although endowed with the same formal competences (Hytönen and Ahlqvist, 2019), represents quite different contexts and conditions for the work with place-based development interventions. This approach has guided the way in which we designed our empirical study and categorised the municipalities into groups.

In the discussion on the decentralisation of development policy, it is important to highlight the different ways in which places are dependent on geographically broad relationships for local economic activities. This involves acknowledging that regional problems are largely the effects of geographically broad structural shifts, and that local interventions may not have access to sufficient resources to counterbalance these (Martin and Sunley, 2015). In relation to such debates and findings, the arguments about decentralised approaches to development interventions should not be interpreted as simplistic ones which assume that general convergence may develop. Arguments are formulated so that 'if convergence is to be promoted, this is to be done by development rather than by redistribution' (Barca et al., 2012: 146). This has led to questions about the expectations of achievements through regional policy and suggestions that it may be relevant to see this policy as 'a continuing involvement over the long run', rather than being 'expected to solve the regional problem' (Parr, 2015: 389). 
Table I. Four categories of municipalities.

\begin{tabular}{lllll}
\hline $\begin{array}{l}\text { Category of municipalities (total } \\
\text { number) }\end{array}$ & \multicolumn{4}{l}{ Municipalities participating in the questionnaire survey } \\
\cline { 2 - 5 } & $\begin{array}{l}\text { Number of } \\
\text { municipalities } \\
\text { (response rate } \\
\text { for respective } \\
\text { category) }\end{array}$ & $\begin{array}{l}\text { Aggregate change } \\
\text { per category for } \\
\text { local workforce } \\
2010-2018\end{array}$ & $\begin{array}{l}\text { Mean value per } \\
\text { category for } \\
\text { local workforce } \\
2018\end{array}$ & $\begin{array}{l}\text { Number of } \\
\text { municipalities (\% in } \\
\text { respective category) } \\
\text { with decreasing local } \\
\text { workforce 2010-2018 }\end{array}$ \\
\hline Cities (2I) & $12(57 \%)$ & $80,345(13 \%)$ & 56,656 & 0 \\
Towns (29) & $17(59 \%)$ & $27,060(8 \%)$ & 21,058 & $1(6 \%)$ \\
Rural settlements (40) & $25(63 \%)$ & $6,467(5 \%)$ & 5,460 & $3(12 \%)$ \\
$\begin{array}{l}\text { Rural settlements with a tourism } \\
\text { industry (I5) }\end{array}$ & $12(80 \%)$ & $4,251(8 \%)$ & 5,038 & 0 \\
$\begin{array}{l}\text { All municipalities within the } \\
\text { investigated categories (I05) }\end{array}$ & $66(57 \%)$ & $118,123(11 \%)$ & 18,709 & $4(6 \%)$ \\
All municipalities in Sweden (290) & $181(62 \%)$ & $579,199(13 \%)$ & 17,145 & $30(10 \%)$ \\
\hline
\end{tabular}

The names of the categories are adapted from the standard developed through the Swedish Association of Local Authorities and Regions (Gillingsjö, 2016).

\section{Empirical study and empirical context}

As explained in the introduction above, the investigation reported in this article was conducted using an extensive study design. A questionnaire survey was distributed to all 290 municipalities in Sweden, sending it to the directors of local industry offices for local authorities, who can be described as economic development practitioners (Cleave and Arku, 2017). The local industry office is the established name for the function of local authorities involving the management and coordination of local development interventions. The questionnaire survey ended in December 2017. We received answers from 183 municipalities, corresponding to a 63 per cent response rate. The survey provided empirical material that enabled us to compare local interventions across authorities in Sweden.

The questions in the survey targeted three main topics. These were (1) the local organisational arrangements for local development offices, (2) the scope of local interventions and (3) how resources for local interventions were sourced through the external relations of local authorities. The discussion in this article focuses on the second and third areas of the questionnaire, which are about the scope of interventions and external relations for the management of development interventions. The questionnaire included both closed and open questions. Respondents' use of the open questions to explain different aspects in their own words provided us with empirical material for a more qualitative reflection on local strategic growth planning. However, the empirical material is generally less detailed when it comes to qualitative aspects of how local growth policy is formed and practised, and here the answers from the closed questions form the main component of the data.

The municipalities analysed in this article are grouped into categories and referred to as 'cities', 'towns' and 'rural settlements', as presented in Table 1. Cities and towns can be described as settlements in the second and third tiers of the national urban system. The rural settlements are divided into two sub-groups, based on whether or not the tourism industry is important for the local industrial profile. This categorisation follows a well-established standard developed through the Swedish Association of Local Authorities and Regions (Gillingsjö, 2016). The selection of these groups of municipalities for our discussion is motivated by our assumption that the impact of scale - reflecting the dimensions of sites pertaining to their social and economic structures - is significant for development interventions. Municipalities characterised by high levels of 
out-commuting to neighbouring cities, which were also found to be less active in terms of development interventions for local industry, are excluded from the analysis (Hermelin and Trygg, 2018). We have also chosen not to include the three largest cities in Sweden, since we assume that they possess complex organisations for their development interventions, which cannot be covered sufficiently by a single respondent in a questionnaire survey.

The response rate among the selection of municipalities analysed in this article was 57 per cent. The empirical material includes survey data from 12 cities, 17 towns and 37 rural settlements. Table 1 presents the data about the different categories of municipalities selected for the discussion of local development interventions. This shows that most of these municipalities have increased their working population during the last decade. However, a decrease is more common in rural settlements, which generally have small labour markets. There are important size differences between the groups of settlements regarding average working population, ranging from 56,000 for cities to 5,000 for rural settlements with a tourism industry.

\section{Empirical context of a unitary state with extensive mandates for local policy}

In this article, our approach to what is included in local development interventions is quite broad. This policy area is defined through its general aim to give wide support to local development, with a focus on local industrial and labour-market development, rather than through thematic demarcation. The following list of measures summarises what we consider to be involved in the scope of local development interventions (Sager, 2011):

- Urban and local economic development (e.g. city and place marketing; platforms and networks for communication; and collaboration across social sectors and organisations);

- Infrastructure and welfare services provision (e.g. local roads and public spaces; broadband; education);
- Management of housing and commercial areas (e.g. physical planning; urban regeneration initiatives).

The first area in this list covers strategies for collaborative work across sectors and organisations within the local environment to facilitate and drive local development. This refers to interventions for which, in general, the involvement of local bodies is nonstatutory and interventions within a fast-moving field. In contrast to this first area, the second and third areas, for infrastructure and welfare service provision and for housing and physical planning, are in general more regulated in terms of the distribution of mandates and responsibilities across the levels of the planning system, which means more stable structures for planning procedures.

While this list is quite general, the extent to which local authorities have mandates and responsibilities within the different areas to which it applies varies across different national planning systems. This means that local authorities have different capabilities in terms of acting effectively on development (Filippetti and Sacchi, 2016). This motivates an acknowledgement that the way in which local authorities develop local interventions needs to consider variations in the structure of the general functions of local authorities across national contexts (Stoker, 2011). Hence, we need to explain some aspects of the planning system within Sweden, which is the empirical context for the investigation presented in this article.

National regulations dictate the tasks of local authorities. Substantial tasks devolved to the local planning level are an important reason why local authorities in Sweden have developed into extensive organisations with large financial budgets. Local authorities leverage local income tax and in Sweden they employ around 20 per cent of the total national workforce. Important mandatory tasks for local authorities include welfare services (social care, primary and secondary education), physical planning and local physical infrastructure (streets, water and sewage), waste management, emergency services and civil defence, libraries and housing. The national government also lists non-mandatory tasks for 
municipalities, which include industrial development and local development interventions.

The history of local development policy in Sweden can be considered to have commenced in the early 1980s, under the rubric of industrial policy (Henning, 1983). Before this period, responsibility for growth policy was primarily in the hands of national government. The period since the 1980s has involved continuous decentralisation, as well as a reformulation of the remit of development policy. Since the 1990s, local growth policy has been described as being established among local authorities more generally (Lidström, 1998). The evolution of local development interventions in Sweden through local authorities has been described as starting with a strong focus on organising dialogues with local industry. Although the activities of local development interventions have expanded over time in different directions and for a wide range of local interventions, dialogue with local industry remains a key function of local industry offices. Sweden's accession to the EU in 1995 was an important moment, and since then development policy has shifted significantly from the national to the EU scale. This is the context within which the decentralisation of development policy to sub-national levels has continued. Our empirical material shows that all municipalities are engaged in these tasks.

In summary, it can be stated that Swedish municipalities have three basic roles: to manage local democratic systems and authority mandates, to deliver local infrastructure and welfare services, and to be development partners (Sveriges Kommuner och Regioner (SKR), 2020). The respondents to the questionnaire survey representing the local industry offices mainly focus on the role of being a development partner.

There are substantial variations between municipalities in Sweden in terms of population size, demographic development, level of urbanisation and the scale of geographical territories. Although Sweden's fairly strong national population growth in recent years has seen most cities and towns growing, in general the country remains sparsely populated, with large areas experiencing shrinking populations. Regardless of the population size, the regulation of the competences of local municipalities applies equally to all 290 local authorities in Sweden.

Sweden can generally be described as a strong unitary state with comparatively strong mandates and resources for local authorities to act upon. In contrast, the regions have a rather weak position in terms of policy. However, their role has undergone a transformation in recent years. Since 2019, all regions in Sweden have established organisations to oversee their extended responsibilities for regional development policy. The Swedish government's programme for regional development raises expectations of closer dialogue and coordination between regions through their extended mandates for development policy - and local municipalities (Regeringen, 2015).

\section{Local development policy: similarities and variations across different local environments}

This section presents and discusses the results of the empirical study, comparing local development interventions across the categories of municipalities: cities, towns and rural settlements.

\section{Scope of local development interventions}

In terms of the scope for local development interventions, the results of the questionnaire show that this includes a repertoire of tasks. Facilitating dialogue with local businesses was the original task of local industry offices when they were inaugurated across the municipalities during the 1980s. The questionnaire survey included various questions about how local industry offices communicate with different constellations and networks of actors within local industry, which are considered to be quite important for local interventions (Bafarasat and Baker, 2016; Barca et al., 2012; Vázquez-Barquero and RodríguezCohard, 2016). Table 2 shows that, in relation to this aspect, almost all respondents explained that they had frequent contact with the local business network. The key focus of local development policy on facilitating relationships between the local authority and local companies means that it is quite common to organise local industrial advisory committees, which 
Table 2. Scope of local development interventions through the investigated local authorities.

\begin{tabular}{|c|c|c|c|c|c|}
\hline & $\begin{array}{l}\text { Cities } \\
\text { (number) and } \\
\text { percentage of } \\
\text { all } 12\end{array}$ & $\begin{array}{l}\text { Towns } \\
\text { (number) and } \\
\text { percentage of } \\
\text { all } 17\end{array}$ & $\begin{array}{l}\text { Rural } \\
\text { settlements } \\
\text { (number) and } \\
\text { percentage of } \\
\text { all } 40\end{array}$ & $\begin{array}{l}\text { Rural settlements } \\
\text { with tourism } \\
\text { (number) and } \\
\text { percentage of } \\
\text { all I5 }\end{array}$ & $\begin{array}{l}\text { All responding } \\
\text { municipalities } \\
\text { (number) and } \\
\text { percentage of } \\
\text { all } 66\end{array}$ \\
\hline $\begin{array}{l}\text { Frequent dialogues with local } \\
\text { business network }\end{array}$ & (I2) $100 \%$ & (17) $100 \%$ & (25) $100 \%$ & (II) $92 \%$ & (65) $98 \%$ \\
\hline $\begin{array}{l}\text { Organising local industry advice } \\
\text { committee }\end{array}$ & (6) $50 \%$ & (12) $71 \%$ & (I0) $40 \%$ & (10) $83 \%$ & (38) $57 \%$ \\
\hline $\begin{array}{l}\text { Frequent dialogues with chamber } \\
\text { of commerce }\end{array}$ & (12) $100 \%$ & (17) $100 \%$ & (16) $64 \%$ & (6) $50 \%$ & (5I) $77 \%$ \\
\hline Support for business development & (I0) $83 \%$ & (13) $76 \%$ & (I8) $72 \%$ & (17) $71 \%$ & (58) $88 \%$ \\
\hline Place marketing & (10) $83 \%$ & (12) $71 \%$ & (I4) $56 \%$ & (6) $50 \%$ & (42) $64 \%$ \\
\hline $\begin{array}{l}\text { Integrated with work for land } \\
\text { exploitation and supply of physical } \\
\text { infrastructure }\end{array}$ & (10) $83 \%$ & (II) $65 \%$ & (22) $88 \%$ & (II) $92 \%$ & (58) $88 \%$ \\
\hline $\begin{array}{l}\text { Integrated with work for } \\
\text { comprehensive planning }\end{array}$ & (5) $42 \%$ & (I2) $71 \%$ & (10) $40 \%$ & (6) $50 \%$ & (33) $50 \%$ \\
\hline $\begin{array}{l}\text { Integrated with work for } \\
\text { education and skills formation }\end{array}$ & (8) $67 \%$ & (7) $41 \%$ & (17) $68 \%$ & (7) $58 \%$ & (39) $59 \%$ \\
\hline
\end{tabular}

bring together representatives from local business, politics and administration for joint discussions. Such committees can be described as representing formalised reference bodies for local policy, with representation from local industry. This could also be seen as important for knowledge creation and learning (Jonas and Moisio, 2018). Table 2 shows that such advisory committees are more commonly present in towns and rural settlements with a tourism industry than in cities and other rural settlements. This can be interpreted as signalling closer relationships between the local authority and the private sector, and possibly also stronger social capital, within smaller environments. The causal relationship between the local presence of industrial advisory committees and local social capital is, however, complex. These committees may represent relationships of trust as well as situations of negotiation, for which the presence of large international companies may be a pertinent aspect.

In contrast to the continuous dialogues with local businesses, contact with a chamber of commerce varied quite substantially and was most common in the cities and towns. This reflects the more regular presence of chambers of commerce within urban environments, compared with rural settlements. While it may be assumed that it is easier to organise communication with local industry in smaller communities with a smaller number of actors, the results also indicate problems for these environments, where there are fewer local actors with whom to connect.

Engagement in facilitating support for business development and place marketing was explained to be an important work task for the local industry offices, particularly in cities. Since around the 1970s, place marketing has been a task for local authorities in Sweden (Syssner, 2012). The question of whether local authorities work to facilitate support for business development is a delicate issue which requires careful interpretation of the survey results. This matter of delicacy stems from the in-built negotiations within local authorities through their different roles and how they interact. The involvement of local authorities in facilitating business development can also be an aspect of task-sharing with other local and regional organisations with missions to support economic development. The local structures of organisations may explain why industry offices for rural settlements with a tourism industry have the lowest 
involvement in place marketing. This is because tourism-sector development in sparsely populated areas is largely managed through regional - and not local - bodies (Svensson, 2019). In general, the boundary between local and regional bodies and other sub-national collaborative networks for development interventions is quite unsettled and undergoing constant change, as the discussion below on relationships within the planning sector for development interventions will discuss in greater detail.

The argument that locally grounded strategies for development are "more likely to be successful if they are "multidimensional" (Rodríguez-Pose and Wilkie, 2019: 24) motivated us to include questions about how the interventions of local industry offices involved becoming integrated across different task fields of the local authority. The results could confirm such integration and, in this way, indicate multidimensional interventions. In general, the results of our survey, summarised in Table 2, show that there is stronger integration with interventions through the 'hard sectors' (i.e. physical planning and local infrastructure) than through 'soft sectors' (i.e. labourmarket interventions and education). We consider this to be an expression of policy integration, which is found to vary across categories of municipalities. The comparatively high level of involvement of towns through their development offices for comprehensive planning can be understood to reflect the fact that these are smaller organisations compared with cities, and that such smaller organisations may facilitate communication across municipalities' different specialisations. Comparing this with rural settlements, with their low levels of engagement in comprehensive planning, there is less need for such planning work because, in general, population and industry are not expanding within rural municipalities. This is in contrast to towns and cities, which are experiencing population growth, and hence have a greater need for comprehensive and physical planning work. The lower share of involvement within comprehensive planning for cities may be interpreted as reflecting the fact that these bodies are larger organisations and hence that integration across offices is more demanding to organise.

The similar levels of involvement by development offices in education in rural settlements and cities may derive from different factors. While cities are generally experiencing strong growth, resulting in a high demand for education, the involvement in education through local industry offices in rural settlements may be interpreted as signalling the precarious situation of schools in such environments with small populations. Thus, the work relating to education is likely to be about expansion in cities, while in rural settlements it involves maintaining institutional resources for schools and other educational facilities.

Although the empirical results presented above describe how local development work involves policy integration, which bridges across the different roles of municipalities, the survey also reveals tense relationships between local authorities' different roles. These different roles mean different logics for various parts of the organisation and explain why uneasy relationships are experienced between local industry offices and other functions. One of these relates to the non-statutory status of local growth policy and development interventions, and how our respondents representing local industry offices experience this as requiring continuous efforts to demonstrate the importance of their work. Previous studies have described how the directors of local development endeavour to change attitudes among their colleagues within the local authority (Persson, 2010). In general, it can be argued that the non-statutory status of local growth interventions offers a margin for manoeuvre for individual local authorities, while they face a constant challenge in terms of how this policy is legitimised and appreciated (Mäntysalo et al., 2015).

To summarise this section about the way in which respondents for local industry offices explain what they do within the framework of local development policy, their broad engagement in work with place marketing and facilitating business development can be interpreted as revealing that the decentralisation of development policy (Pike et al., 2017; RodriguezPose and Sandall, 2008; Tomaney, 2014) involves expanding the repertoire of interventions through local authorities. In addition, the integration of the work carried out through local industry offices with different specialisations of the local authorities signals that local development work has become a 
concern across local authorities more generally. This contrasts with the earlier period of quite specialised local industry offices, which primarily focused on dialogues and information sharing with local industry. However, it was also described above how the integration of local development tasks into local authorities causes complex tensions within the organisation of local policy. The place context of industrial structures and the impact of anchor tenants on local ideals and expectations explain why engagement within local development interventions varies. This relates to the way in which expectations and visions generate agency for policy and planning (Hassink et al., 2019).

\section{External relations of local development interventions}

While the variations in scope across the different categories of municipalities were discussed above, this section turns to the factors that impact upon the capacity of local authorities to pursue development strategies by exploring how resources are harnessed through external relations within the planning sector. The results described in this section are based on the set of questions in the survey that asked about the ways in which vertical and horizontal relations within the planning sector contributed with resources for local development interventions.

Table 3 illustrates that towns in particular appreciate the relationship with regions and endorse them as being quite important in terms of contributing with resources for development interventions. In contrast, cities find it comparatively irrelevant. Within the Swedish planning system, regions represent a planning body with the political-administrative scale of counties, which have recently gained reinforced responsibilities for development policy. This variation across the different categories of municipalities in the endorsement of relations with the regions may be explained by the differing organisational capacities of municipalities to mobilise resources for development policy. Thus, because towns have fewer resources for development policy than cities, they find support from the regions to be important. This result aligns with previous studies, which have illustrated the complicated relationships between cities and regions in the context of the regions' expanding mandates for development policy. This relates to how municipalities are experiencing the threat of losing their mandates through the process of upscaling from local to regional levels for development interventions (Hermelin and Wänström, 2017).

In contrast to this quite complicated scale relation between municipalities and regions, the scale relations between municipalities and the national state are more clear-cut, although not without a flavour of negotiation. The survey results illustrate that municipalities see relationships with national bodies as important. Table 3 shows that the assessment of resources derived through relationships with the Swedish Agency for Economic and Regional Growth (Tillväxtverket) is fairly even across the different categories of municipalities, which is explained by the substantial and wide array of tasks the government directs towards this body. In contrast, cities are most positive towards the importance of resources derived from relationships with the quite specialised national agencies, represented in Table 3 through Sweden's innovation agency (Vinnova) and the Swedish Energy Agency (Energimyndigheten). This, again, is likely to reflect the varying capacities of municipalities of different sizes to manage development, and in these cases for cities to gain resources through comparatively specialised state agencies for innovation and energy transition.

Opinions about relationships with the EU for local development capacity also diverge between the categories of municipalities. When Sweden joined the EU in 1995, this involved rescaling development policy from the national to the supranational level. It has also involved a much slower process of rescaling towards the regional level and the very recent consolidation of regions in Sweden, as mentioned above. In general, regional development policy through the EU has involved channelling resources to sparsely populated areas. This explains why the rural municipalities considered relations with the EU to be quite important for accessing resources to pursue development interventions. In comparison, cities are relatively indifferent to the role of the EU in terms of local development interventions. 
Table 3. Respondents' assessments of contributions with resources to local development interventions through external relations within the planning sector.

\begin{tabular}{|c|c|c|c|c|c|}
\hline & $\begin{array}{l}\text { Cities } \\
\text { (number) } \\
\text { and } \\
\text { percentage } \\
\text { of all } 12\end{array}$ & $\begin{array}{l}\text { Towns } \\
\text { (number) } \\
\text { and } \\
\text { percentage } \\
\text { of all } 17\end{array}$ & $\begin{array}{l}\text { Rural } \\
\text { settlements } \\
\text { (number) and } \\
\text { percentage of } \\
\text { all } 40\end{array}$ & $\begin{array}{l}\text { Rural settlements } \\
\text { with tourism } \\
\text { (number) and } \\
\text { percentage of } \\
\text { all I5 }\end{array}$ & $\begin{array}{l}\text { All responding } \\
\text { municipalities } \\
\text { (number) and } \\
\text { percentage of } \\
\text { all } 66\end{array}$ \\
\hline $\begin{array}{l}\text { Relations with regions contribute } \\
\text { with resources }\end{array}$ & (4) $33 \%$ & (I3) $81 \%$ & (16) $64 \%$ & (7) $58 \%$ & (40) $61 \%$ \\
\hline $\begin{array}{l}\text { Relations with Swedish Agency of } \\
\text { Economic and Regional Growth } \\
\text { contribute with resources }\end{array}$ & (7) $58 \%$ & (II ) $65 \%$ & (15) $60 \%$ & (4) $33 \%$ & (47) $71 \%$ \\
\hline $\begin{array}{l}\text { Relations with Sweden's Innovation } \\
\text { Agency contribute with resources }\end{array}$ & (6) $50 \%$ & (7) $41 \%$ & (7) $28 \%$ & (2) $17 \%$ & (22) $33 \%$ \\
\hline $\begin{array}{l}\text { Relations with Swedish Energy } \\
\text { Agency contribute with resources }\end{array}$ & (3) $25 \%$ & (3) $18 \%$ & (2) $8 \%$ & (I) $8 \%$ & (9) $14 \%$ \\
\hline $\begin{array}{l}\text { Relations with EU contribute with } \\
\text { resources }\end{array}$ & (4) $33 \%$ & (II) $65 \%$ & (2I) $84 \%$ & (7) $58 \%$ & (43) $65 \%$ \\
\hline $\begin{array}{l}\text { Collaborations with other local } \\
\text { authorities contribute with } \\
\text { resources }\end{array}$ & (5) $42 \%$ & (8) $47 \%$ & (20) $80 \%$ & (I0) $83 \%$ & (59) $89 \%$ \\
\hline
\end{tabular}

EU: European Union.

In terms of the horizontal relations across different municipalities, the survey results show marked differences between the categories in terms of whether or not collaboration with other municipalities is seen as an important channel for development policy. Table 2 illustrates that such collaboration is most valued by rural municipalities and least valued by cities. This may be explained by the small-scale context of some municipalities, with few collaborative partners in the local environment, which motivates them to expand their networks through collaborations with surrounding local authorities to improve access to resources for local development. These results regarding the variations in crossmunicipality collaboration are relevant when arguing that municipalities might be too small or weak to be able to effectively finance a function designed to manage local interventions for local development (Rodríguez-Pose and Wilkie, 2019). However, although organisational capacity may be shared across different local authorities, at the time when our questionnaire survey was distributed, each municipality in Sweden had at least one employed official with responsibility for organising local development interventions.

Thus, in summary, this picture of respondents' appreciation of how horizontal and vertical relations within the planning sector have contributed to capacity for local development interventions illustrates quite different profiles across the different categories of municipalities. Sourcing support from regions and the EU can be interpreted as compensating for the lower capacity of smaller municipalities, for which EU policy and programmes are important. Meanwhile, cities' sourcing of support from national innovation and energy agencies can be understood as signalling the stronger capacity of larger urban environments to organise for innovation and social transformation. These differences have impacts on local development.

\section{Concluding discussion}

The aim of this article has been to investigate how the decentralising of development policy is adopted through local planning and how this varies across 
different geographical environments. This has involved investigating the scope of local development interventions and how local development planning entails both horizontal and vertical relations within the planning system. The empirical material for this investigation is extensive and covers municipalities across Sweden. For this closing discussion, we summarise our analysis of the empirical results and draw conclusions.

First, both the scope of interventions and the structures of external relations to source capacity for local development interventions vary across the different categories of municipalities. In general, cities were found to work with a broader repertoire of interventions than the other categories, including business support and branding activities, which are not traditional tasks for local authorities. In addition, there are differences between the categories of municipalities in the ways in which they valued how resources gained through external relations were important for local development interventions. Cities appreciated relations with national agencies, while towns appreciated relations with the region, and rural municipalities appreciated relations with other municipalities and with the EU. Overall, this highlights the importance of the interplay between rescaling and multi-scalar relationships (Jonas and Moisio, 2018). In more concrete terms, it reflects the strength of the impacts of programmes designed from the top down on what decentralised interventions will involve and shows that the top-down programmes are unevenly adopted across different urban and rural environments. This contributes with a nuanced picture of what the decentralisation of development interventions implies. In the Swedish case, this decentralisation seems to more closely resemble delegation than devolution (Pike et al., 2016), which is nurtured to an important extent by soft steering through the EU, national bodies and regions, expressing expectations that local authorities will act. However, the decentralisation of expectations may not be accompanied by a decentralisation of resources. Hence, the capacity of municipalities to engage in local development interventions relates to their ability and strategic choices to become involved with national and EU programmes. Comparing these findings with earlier research arguing that the smaller structural capacities of small municipalities challenge their ability to become involved with wider programmes (Huggins and Clifton, 2011), the results from this article support this for national programmes. Hence, decentralised development policy risks being unable to solve problems for places with small and decreasing populations and labour markets. This is an important foundation for the argument in favour of a 'place-sensitive distributed development policy' in which the place-based approach involves tailoring instruments to the structurally specific prospects of different geographies (Iammarino et al., 2019: 290).

Second, the results of this article have illustrated the importance of reflecting upon how particular national planning systems influence the implications of the general international trend towards the decentralisation of local development policy (Pelkonen, 2016). Thus, in the Swedish case, the role of local authorities for local development interventions, which are unregulated but expected, becomes quite vague in comparison with their extensive and regulated local responsibilities for organising welfare services and physical planning. Nevertheless, the general and recent wave across Swedish municipalities to consolidate local industry offices more closely within the office for the highest political steering level of local government indicates that local development interventions are increasingly considered a strategic task for municipalities - in contrast to being primarily operational ones. This also explains why the engagement with local policy for development radiates out and involves engagement across the different departments and tasks of municipalities, and thus renders the demarcation of local development interventions indistinct. Hence, the particular context of relatively resourceful local authorities in Sweden can be considered to offer conducive conditions for developing a strategic, integrated and bottom-up approach to local development interventions. While this reflects the quite substantial capacity of local authorities to design place-based development policy in terms of adapting to local 'social, cultural and institutional characteristics ... [to] build on the embedded local knowledge [and create a] multisectoral policy framework' (Barca et al., 2012: 139, 149), there are also structural conditions that challenge such capacity building for local development interventions. This refers to the descriptions running 
throughout our empirical material of negotiation situations within the local authorities between the unregulated but expected local development work and the mandatory and strongly institutionalised tasks of local authorities for welfare services and physical planning. This leads to aspects of precarious and unstable status for local development policy.

Overall, these final conclusions highlight the importance of reflecting upon and unpacking what the decentralisation of development interventions implies 'on the ground'. This includes envisioning how strategising for development interventions is designed through vertical and horizontal relations within the planning sector, and how the capacities of local development policy vary across different geographical structures. The latter aspect, about the varying capacities of local planning to mobilise for bottom-up development, for which the weaker regions remain weak, constitutes a vibrant debate within geography. However, to the best of our knowledge, the ways in which the varying national political and planning systems impact upon the scope of local development policy for different local environments have received comparatively little attention. Thus, we hope that the discussion in this article, in which we have taken into consideration how the particular profile of responsibility and the mandates of municipalities in Sweden impact the adoption of development policy, will provide inspiration for future research exploring how the national structure of planning systems affects the uneven local adoption of decentralised development policy.

\section{Declaration of conflicting interests}

The author(s) declared no potential conflicts of interest with respect to the research, authorship and/or publication of this article.

\section{Funding}

The author(s) received no financial support for the research, authorship and/or publication of this article.

\section{ORCID iDs}

Brita Hermelin (iD) https://orcid.org/0000-0003-2404-0624

Kristina Trygg iD https://orcid.org/0000-0003-0121-2729

\section{References}

Bachtler J and Yuill D (2001) Policies and strategies for regional development: a shift in paradigm? Regional and Industrial Policy Research Paper No. 46. Strathclyde: University of Strathclyde.

Bafarasat AZ and Baker M (2016) Strategic spatial planning under regime governance and localism: experiences from the North West of England. Town Planning Review 87(6): 681-703.

Bailey D, Pitelis C and Tomlinson PR (2018) A placebased developmental regional industrial strategy for sustainable capture of co-created value. Cambridge Journal of Economics 42(6): 1521-1542.

Barca F (2009) An agenda for a reformed cohesion policy: a place-based approach to meeting European Union challenges and expectations. Independent report for Danuta Hübner, Commissioner for Regional Policy.

Barca F, McCann P and Rodríguez-Pose A (2012) The case for regional development intervention: placebased versus place-neutral approaches. Journal of Regional Science 52(1): 134-152.

Bowden A and Liddle J (2018) Evolving public sector roles in the leadership of place-based partnerships: from controlling to influencing policy? Regional Studies 52(1): 145-155.

Brenner N (1999) Globalisation as reterritorialisation: the re-scaling of urban governance in the European Union. Urban Studies 36(3): 431-451.

Brenner N (2003) Metropolitan institutional reform and the rescaling of state space in contemporary Western Europe. European Urban and Regional Studies 10(4): 297-324.

Broadhurst K (2018) In the pursuit of economic growth: drivers and inhibitors of place-based partnerships. Regional Studies, Regional Science 5(1): 332-338.

Camagni R and Capello R (2015) Rationale and design of EU cohesion policies in a period of crisis. Regional Science Policy and Practice 7(1): 25-47.

Cleave E and Arku G (2017) Putting a number on place: a systematic review of place branding influence. Journal of Place Management and Development 10(5): 425-446.

Crawford TW (2020) Scale, Analytical. In: International Encyclopedia of Human Geography (2nd ed.), 89-96 Oxford: Elsevier.

Crescenzi R and Giua M (2016) The EU Cohesion Policy in context: does a bottom-up approach work in all regions? Environment and Planning A 48(11): 2340-2357.

Crivello S (2015) Urban policy mobilities: the case of Turin as a Smart City. European Planning Studies 23(5): 909-921. 
Farole T, Rodríguez-Pose A and Storper M (2011) Human geography and the institutions that underlie economic growth. Progress in Human Geography 35(1): 58-80.

Filippetti A and Sacchi A (2016) Decentralization and economic growth reconsidered: the role of regional authority. Environment and Planning C: Government and Policy 34(8): 1793-1824.

Gillingsjö E (2016) Kommungruppsindelning 2017: omarbetning av Sveriges kommuner och landstings kommungruppsindelning. Stockholm: Sveriges Kommuner och Landsting (SKL).

Gualini E (2006) The rescaling of governance in Europe: new spatial and institutional rationales. European Planning Studies 14(7): 881-904.

Hassink R, Isaksen A and Trippl M (2019) Towards a comprehensive understanding of new regional industrial path development. Regional Studies 53(11): $1636-1645$.

Henning R (1983) Kommunal näringspolitik - ett nytt inslag i den svenska förhandlingsekonomin. Ekonomisk debatt 5: 333-340.

Hermelin B and Trygg K (2018) Lokalt utvecklings- och tillväxtarbete. En studie av kommunernas näringlivsfunktion. CKS rapport 2018:11. Linköping: Centrum för kommunstrategiska studier, Linköpings universitet.

Hermelin B and Wänström J (2017) Att organisera för regional utveckling: erfarenheter från regionbildning $i$ Östergötland. CKS rapport 38. Linköping: Centrum för kommunstrategiska studier, Linköpings universitet.

Huggins R and Clifton N (2011) Competitiveness, creativity, and place-based development. Environment and Planning A 43(6): 1341-1362.

Hytönen J and Ahlqvist T (2019) Emerging vacuums of strategic planning: an exploration of reforms in Finnish spatial planning. European Planning Studies 27(7): 1350-1368.

Iammarino S, Rodriguez-Pose A and Storper M (2019) Regional inequality in Europe: evidence, theory and policy implications. Journal of Economic Geography 19(2): 273-298.

Jonas AEG and Moisio S (2018) City regionalism as geopolitical processes: a new framework for analysis. Progress in Human Geography 42(3): 350-370.

Keating M (2021) Beyond the nation-state: territory, solidarity and welfare in a multiscalar Europe. Territory, Politics, Governance 9(3): 331-345.

Kline P and Moretti E (2014) People, places and public policy: some simple welfare economics of local economic development programs. NBER Working Papers 19659. Cambridge, MA: NBER.
Li Y and Jonas AEG (2019) City-regionalism as countervailing geopolitical processes: the evolution and dynamics of Yangtze River Delta region, China. Political Geography 73: 70-81.

Lidström A (1998) Utbildning och kommunal utvecklingspolitik. Kommunal ekonomi och politik 2(2): $21-42$.

McCann E (2017) Governing urbanism: urban governance studies 1.0, 2.0 and beyond. Urban Studies 54(2): 312-326.

McCann E and Ward K (2015) Thinking through dualisms in urban policy mobilities. International Journal of Urban and Regional Research 39(4): 828-830.

MacKinnon D (2011) Reconstructing scale: towards a new scalar politics. Progress in Human Geography 35(1): 21-36.

Mäntysalo R, Jarenko K, Nilsson KL and Saglie I-L (2015) Legitimacy of Informal Strategic Urban Planning - observations from Finland, Sweden and Norway. European Planning Studies 23(2): 349-366.

Martin R (2001) Geography and public policy: the case of the missing agenda. Progress in Human Geography 25(2): 189-210.

Martin R and Sunley P (2015) On the notion of regional economic resilience: conceptualization and explanation. Journal of Economic Geography 15(1): $1-42$.

Montresor S and Vittucci Marzetti G (2011) The deindustrialisation/tertiarisation hypothesis reconsidered: a subsystem application to the OECD7. Cambridge Journal of Economics 35(2): 401-421.

Moodysson J, Trippl M and Zukauskaite E (2017) Policy learning and smart specialization: balancing policy change and continuity for new regional industrial paths. Science and Public Policy 44(3): 382-391.

Morisson A and Doussineau M (2019) Regional innovation governance and place-based policies: design, implementation and implications. Regional Studies, Regional Science 6(1): 101-116.

Muringani J, Fitjar RD and Rodríguez-Pose A (2019) Decentralisation, quality of government and economic growth. Revista de Economia Mundial 51: 25-50.

Neuman M and Hull A (2009) The futures of the city region. Regional Studies 43(6): 777-787.

Neumark D (2020) Place-based policies: can we do better than enterprise zones? Journal of Policy Analysis and Management 39(3): 836-844.

Oancă A (2015) Europe is not elsewhere: the mobilization of an immobile policy in the lobbying by Perm (Russia) for the European Capital of Culture title. European Urban and Regional Studies 22(2): 179-190. 
O'Brien P and Pike A (2019) 'Deal or no deal?' Governing urban infrastructure funding and financing in the UK City Deals. Urban Studies 56(7): 1448-1476.

OECD (2011) OECD Regional Outlook 2011. Building Resilient Regions for Stronger Economies. Paris: OECD Publishing.

Oughton C, Landabaso M and Morgan K (2002) The regional innovation paradox: innovation policy and industrial policy. Journal of Technology Transfer 27(1): 97-110.

Parr JB (2015) Neglected aspects of regional policy: a retrospective view. Environment and Planning $C$ : Government and Policy 33(2): 376-392.

Pelkonen A (2016) Rescaling and urban-regional restructuring in Finland and in the Helsinki region. European Urban and Regional Studies 23(2): 149-166.

Persson B (2010) Lokal och regional näringslivspolitik: konkurrens, samarbete, utveckling. CKS rapport 5. Linköping: Linköpings universitet, Centrum för kommunstrategiska studier.

Persson B and Kitagawa F (2021) Decentralisation and reconfiguration of multilevel research policy: the case of Sweden. In: Bergström T, Franzke J, Kuhlmann $\mathrm{S}$ and Wayenberg $\mathrm{E}$ (eds) The Future of Local Self-Government: European Trends in Autonomy, Innovations and Central-Local Relations. London: Palgrave Macmillan, pp. 173-184.

Pike A, Kempton L, Marlow D, O'Brien P and Tomaney J (2016) Decentralisation: Issues, Principles and Practice. Newcastle upon Tyne: Centre for Urban and Regional Development Studies (CURDS) at Newcastle University.

Pike A, Rodríguez-Pose A and Tomaney J (2017) Shifting horizons in local and regional development. Regional Studies 51(1): 46-57.

Prince R (2012) Metaphors of policy mobility: fluid spaces of 'creativity' policy. Geografiska Annaler, Series B: Human Geography 94(4): 317-331.

Prince R (2014) Consultants and the global assemblage of culture and creativity. Transactions of the Institute of British Geographers 39(1): 90-101.

Puglalis L and Gray N (2016) New regional development paradigms: An exposition of place-based modalities. Australasian Journal of Regional Studies 1(22): 181-201.

Regeringen (2015) Indelning och uppgifter i kommuner och landsting. Stockholm: Regeringen.

Rodríguez-Pose A (2013) Do institutions matter for regional development? Regional Studies 47(7): 1034-1047.

Rodríguez-Pose A (2020) Institutions and the fortunes of territories. Regional Science Policy \& Practice 12(3): 371-386.
Rodríguez-Pose A and Gill N (2004) Is there a global link between regional disparities and devolution? Environment and Planning A 36(12): 2097-2117.

Rodriguez-Pose A and Sandall R (2008) From identity to the economy: analysing the evolution of the decentralisation discourse. Environemnt and Planning $C$ : Government and Policy 26(1): 54-72.

Rodríguez-Pose A and Wilkie C (2019) Strategies of gain and strategies of waste: what determines the success of development intervention? Progress in Planning 133: 100423 .

Roodbol-Mekkes PH and van den Brink A (2015) Rescaling spatial planning: spatial planning reforms in Denmark, England, and the Netherlands. Environment and Planning C: Government and Policy 33(1): 184-198.

Sager T (2011) Neo-liberal urban planning policies: a literature survey 1990-2010. Progress in Planning 76(4): 147-199.

Schneider C and Cottineau C (2019) Decentralisation versus territorial inequality: a comparative review of English City Region Policy Discourse. Urban Science 3(3): 90.

Stoker G (2011) Was local governance such a good idea? A global comperative perspective. Public administation 89(1): 15-31.

Sveriges Kommuner och Regioner (SKR) (2020) Att hantera komplexa samhällsutmaningar: Organisera, styra och leda i samverkan. Stockholm: SKR.

Svensson P (2019) Ansvar för kunskapsutveckling: Regionernas och kommunernas roller och relationer. CKS rapport 2019:8. Linköping: Linköpings universitet, Centrum för kommunstrategiska studier.

Swyngedouw E (2000) Authoritarian governance, power, and the politics of rescaling. Environment and Planning D: Society and Space 18(1): 63-76.

Syssner J (2012) Världens bästa plats? platsmarknadsföring, makt och medborgarskap. Lund: Nordic Academic Press.

Temenos C and McCann E (2012) The local politics of policy mobility: learning, persuasion, and the production of a municipal sustainability fix. Environment and Planning A 44(6): 1389-1406.

Tomaney J (2014) Region and place I: institutions. Progress in Human Geography 38(1): 131-140.

Vázquez-Barquero A and Rodríguez-Cohard JC (2016) Endogenous development and institutions: challenges for local development initiatives. Environment and Planning C: Government and Policy 34(6): 1135-1153.

Viitanen J and Kingston R (2014) Smart cities and green growth: outsourcing democratic and environmental resilience to the global technology sector. Environment and Planning A 46(4): 803-819. 